\title{
DIETA DE PARDIRALLUS MACULATUS (AVES: RALLI- DAE) EN EL PARANÁ MEDIO (SANTA FE, ARGENTINA)
}

\author{
Del barco, o. D. ${ }^{1}, \quad \& \quad$ Beltzer, A. H. ${ }^{2}$
}

\begin{abstract}
RESUMEN
Se dan a conocer los resultados vinculados al espectro trófico, ritmo circadiano de actividad alimentaria, amplitud del nicho trófico, eficiencia alimentaria, tamaño de las presas y selección de habitat de Pardirallus maculatus. Se analizaron 15 estómagos. El espectro trófico resultó compuesto por 12 entidades taxonómicas, integradas por moluscos e insectos. La diversidad trófica acumulada fue 2,89 (Hk) en cuya asíntota se determinó la muestra mínima (p.t.). La amplitud del nicho fue 7,14 (primavera), 4 (verano), 4,54 (otoño), 4,54 (invierno). La eficiencia alimentaria fue de 99,14\%. En lo referente al ritmo circadiano de actividad alimentaria se visualizó un patrón en campana, observándose una mayor actividad en horas previas al mediodía. El índice de preferencia de habitat fue aplicado a las unidades de pajonal y vegetación acuática en los que se obtuvieron valores que señalan alta selección tanto por el pajonal o Panicum spp. $(1,32)$ como por la vegetación acuática $(1,20)$. El tamaño de las presas osciló entre 2,5 y $30,4 \mathrm{~mm}$, siendo más frecuentes las comprendidas entre los 2,5 y $8,00 \mathrm{~mm}$. En función de los resultados obtenidos se señala que Pardirallus maculatus evidencia un nicho efectivo que se manifiesta estacionalmente, siendo la primavera la de mayor diversidad trófica $(7,14)$.

Palabras clave: Pardirallus maculatus, diversidad trófica, nicho trófico, Río Paraná Medio.
\end{abstract}

\section{SUMMARY}

\section{Diet of the spotted rail Pardirallus maculatus (Birds: Rallidae) in the middle Parana river (Argentina).}

Different indexes related to the feeding ecology of Pardirallus maculatus are exposed in this research. The trophic spectrum was composed by 12 taxa, including molluses and insects in fifteen stomachs analized. The accumulated trophic diversity was 2.89 (Hk) which allows to determine the minimum sample. The following values were obtained for the trophic niche amplitude: 7.14 in spring, 4 in summer, 4.54 in autumn and 4.54 in winter. The value of the alimentary efficiency showed was $99.14 \%$. Related to the circadian rithm of alimentary activity, it showed a bell standard, being detected the highest activity a few hours before mid-day. The habitat preference index showed a high sellection for

1.- Pasante en el INALI. Facultad de Humanidades y Ciencias. Ciudad Universitaria Paraje El Pozo. (3000), Santa Fe.

2.- CONICET. Instituto Nacional de Limnología (INALI). J. Macía 1933. (3016) Santo Tomé, provincia de Santa Fe. E-mail inali@ceride.gov.ar

Manuscrito recibido el 2 de julio de 2002 y aceptado para su publicación el 6 de diciembre de 2002. 
grassland of Panicum spp. (1.32) and for aquatic vegetation (1.20). The prey's size varied between 2.5 and $30.4 \mathrm{~mm}$, being the most frecuent those included in the range 2.5-8.0 $\mathrm{mm}$. Pardirallus maculatus have an effective niche that is manifested seasonally, being spring the season with the biggest trophic diversity (7.14)

Key words: Pardirallus maculatus, trophic diversity, trophic spectrum, Middle Paraná River. 